\title{
The effect of supernumerary segments on recombination in Euchorthippus pulvinatus (grasshopper): a comparative study between sexes and populations
}

\author{
J. L. SANTOS \\ Departamento de Genética, Facultad de Biologia, Universidad Complutense, 28040 Madrid, Spain
}

\begin{abstract}
A polymorphism for heterochromatic supernumerary segments in the M7 and S8 chromosomes has been found in three natural populations of the grasshopper Euchorthippus pulvinatus. In two out of three populations the presence of S8 segments on the male side leads to a significant increase in mean cell chiasma frequency compared to individuals lacking segments. The M7 segment also enhances chiasma frequency in the single population studied. Neither segment produces any effect on the female side. Both segments modify chiasma distribution in the carrier bivalents with chiasmata preferentially formed furthest from the segment, at least in heterozygotes. In M7 heterozygotes this effect is more pronounced in males than in females. M7 basic and segment homozygotes have similar chiasma distribution patterns while the distribution patterns differ in S8 homozygotes
\end{abstract}

Keywords: chiasma frequency and distribution, grasshoppers, sex, supernumerary segments.

\section{Introduction}

The existence of supernumerary segments, extra chromosomal material added to some members of the complement, is a common feature among grasshoppers. They are usually associated with the smallest chromosomes and seem to be heterogeneous in nature (Camacho et al., 1984). In many cases they constitute stable polymorphisms. The causes of their maintenance in natural populations, however, remain unknown because there are no consistent data either on the transmission mechanisms or the possible selective advantages of carriers. Putative selective factors have been postulated in relation to the effects that they produce at the endophenotypic level, namely: (i) on the activity of nucleolar organizer regions (Cabrero et al., 1986); (ii) on the mean cell chiasma frequency (Hewitt \& John, 1968) or the between-cell variance in chiasma frequency (Shaw, 1971); and (iii) on chiasma distribution of bivalents carrying them (Miklos \& Nankivell, 1976; Navas-Castillo et al., 1985; de la Torre et al., 1986).

It has been argued that the main function of segments is the regulation of variation present within and between populations through the recombination pro- cess (John, 1981). However, this claim has been based only on observations on the male side, and usually from studies of single populations of a given species. In this paper, the effects of supernumerary segments on chiasma conditions in males and females of the grasshopper Euchorthippus pulvinatus, collected from three populations, are presented.

\section{Materials and methods}

Mature adults of Euchorthippus pulvinatus were collected from three natural populations from the province of Madrid: Valdemoro (1987), Miraflores (1988) and Desviación (1989). Males were dissected and their testes fixed in acetic ethanol 1:3 prior to making $\mathrm{C}$-banded squash preparations according to the method described by Santos \& Giráldez (1978). Females were maintained in cages in laboratory conditions until required. Chromosomal constitution was determined from cells of the gastric caeca and follicular cells of ovarioles. Animals were injected with 0.2 per cent colchicine solution and were killed $4 \mathrm{~h}$ later. Squash preparations of oocyte first metaphases were made using the method of Henriques-Gil et al. (1986). Mean chiasma frequencies were obtained from 
10 spermatocytes per male insect and five oocytes per female. The position of the single chiasma in M7 and S8 bivalents was classified by eye as proximal, interstitial or distal with respect to the centromere in a variable number of meiocytes per male.

\section{Results}

Euchorthippus pulvinatus has 17 chromosomes in the male $(16+\mathrm{X})$ and 18 in the female $(16+\mathrm{XX})$. Three pairs of autosomes are long and submetacentric, while the remaining five pairs and the $\mathrm{X}$ are of medium to small size and telo- or subtelocentric. All members of the complement show centromeric C-heterochromatin. The two smallest chromosomes (M7 and S8) show qualitative variation in their C-banding pattern; the M7 chromosome may have a thick C-band at or near the telomere and the $\mathrm{S} 8$ chromosome a thin interstitial C-band near the centromere (Fig. 1). Three karyotypes for each chromosome can be found: homozygous for the chromosome without the C-band (BB), heterozygous (BS), and homozygous for the C-band (SS).

\section{Mean chiasma frequencies}

The presence of an S8 segment in one or two doses increases the mean cell chiasma frequency of male carriers in Desviación and Miraflores populations by 0.54 and 0.63 chiasmata per SMC. The trend is similar but non-significant in the Valdemoro population.

In females the mean cell chiasma frequencies are lower than the corresponding male values (Table 1) despite females having an extra bivalent formed by the sex chromosomes. No effect of S8 segments is observed in females.

In the M7 chromosomes in the Desviación population, the presence of a segment increases the mean chiasma frequency of male carriers but, again, has no effect on the female side (Table 2).

An analysis of the effect on chiasma frequency produced by the interaction between segments on M7 and S8 chromosomes could only be performed in males due to the low frequency of the M7 segment chromosome in natural populations (Santos \& Giráldez, 1982). Data from the Desviación population do not reveal significant evidence of segment dosage effect (see Table 2).

\section{Chiasma distribution in monochiasmate $M 7$ and $S 8$ bivalents}

In basic and structural homozygotes of the $\mathrm{M} 7$ bivalent from Desviación, chiasmata are located all along the chromosome. In heterozygotes, however, most chias-

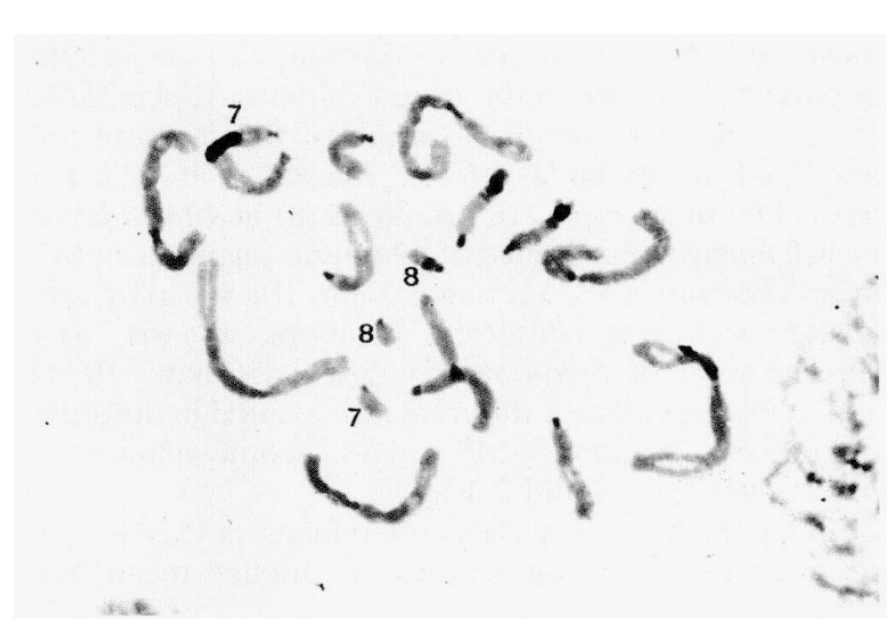

Fig. $1 \mathrm{C}$-banded mitotic metaphase I cell obtained from gut caeca of a female double heterozygous M7BS, S8BS.

mata are proximal (Fig. 2a, Table 3). M7 BS bivalents from Valdemoro show both an enhanced frequency of proximal chiasmata and a relatively high frequency of distal associations ( 42 per cent) (Fig. 2b), the chiasmate nature of which has recently been demonstrated (Santos \& Esteban, 1990). This may indicate a difference in the segments, with one strictly terminal (Desviación and Miraflores) and the other subterminal (Valdemoro).

To study chiasma distribution in basic homozygous females, M7 and S8 BB bivalents were grouped because they are indistinguishable by conventional staining. In females of Desviación and Valdemoro populations, a single dose of the segment greatly increases the frequency of interstitial chiasmata (Fig. 2c). Again distal chiasmata (D2) in heterozygotes from Valdemoro were observed (Fig. 2d).

In the $\mathrm{S} 8$ bivalent in males of the Desviación population, the presence of segments shifts the chiasmata progressively to more distal locations (Table 4). BS bivalents are significantly different from BB bivalents, while SS bivalents are significantly different from BS. A similar trend is also observed in BB and BS bivalents from the Valdemoro population.

\section{Discussion}

The results obtained in this study on the effect of segments on chiasma frequency indicate a complex situation. (i) In $E$. pulvinatus the effect of extra heterochromatin on chiasma frequency is sex-dependent. Thus males in some populations are affected while females are not. Further studies of other species are needed here. (ii) The effect may be dependent on the genetic background. Thus the segments increase 
mean cell chiasma frequency of male carriers in two populations but not in the third (Valdemoro, see Table 1). (iii) The size and the location of the segment are unrelated to chiasma effects. Increases in chiasma frequency of carriers are produced (a) in Chorthippus parallelus by the presence of telomeric segments in M7 or S8 chromosomes (Hewitt \& John, 1968), (b) by segments occupying different positions in the S11 chromosome of Stethophyma grossum (Shaw, 1971) and (c) by segments of different size located in different chromosome regions of M7 and S8 chromosomes of $E$. pulvinatus (Table 1 and 2; Fig. 1).

The presence of segments often leads, at least in one sex and in some populations, to higher mean cell chiasma frequencies and perhaps to cross-over events in certain chromosome regions where these are usually lacking. Thus a selective advantage for the whole population, although not the carriers themselves, has been postulated. However, the adaptative significance of variation in chiasma frequency remains unclear and subject to controversy (see for instance Rees \& Dale, 1974; Maynard-Smith, 1977).

The effect of segments on chiasma distribution within bivalents of E. pulvinatus (Tables 3 and 4) supports the idea that this is a general phenomenon which is independent of the nature and location of the segment (Camacho et al., 1984). Segments lead to chiasma redistribution such that regions furthest from

Table 1 Mean cell chiasma frequencies of males and females of E. pulvinatus collected from different populations and displaying different karyomorphs for the S8 chromosome. All individuals were $\mathrm{M} 7 \mathrm{BB} . N=$ nos of individuals

\begin{tabular}{|c|c|c|c|c|c|c|c|}
\hline Population & Karyomorph & $\begin{array}{l}\text { Males } \\
\text { Xta/cell }\end{array}$ & $N$ & $\begin{array}{l}t \text {-test } \\
\text { (d.f.) }\end{array}$ & $\begin{array}{l}\text { Females } \\
X^{-} \mathrm{ta} / \text { cell }\end{array}$ & $N$ & $\begin{array}{l}t \text {-test } \\
\text { (d.f.) }\end{array}$ \\
\hline \multirow{3}{*}{$\begin{array}{c}\text { Desviación } \\
1989\end{array}$} & $\mathrm{BB}$ & $13.13 \pm 0.16$ & $10)$ & $220 *$ & $13.37 \pm 0.2$ & $8\}$ & \multirow{3}{*}{$\begin{array}{c}0.58 \\
(21) \\
0.57 \\
(18)\end{array}$} \\
\hline & BS & $13.67 \pm 0.17$ & $10)$ & $\begin{array}{l}2.29^{\circ} \\
(18) \\
0.65\end{array}$ & $13.23 \pm 0.14$ & 15) & \\
\hline & SS & $13.81 \pm 0.13$ & 10 & (18) & $13.40 \pm 0.32$ & 5 & \\
\hline \multirow{3}{*}{$\begin{array}{c}\text { Miraflores } \\
1988\end{array}$} & $\mathrm{BB}$ & $13.31 \pm 0.18$ & $10)$ & \multirow{3}{*}{$\begin{array}{l}2.61^{*} \\
(18)\end{array}$} & $13.31 \pm 0.17$ & 9 & \\
\hline & BS & $13.85 \pm 0.11$ & $10\}$ & & $13.31 \pm 0.17$ & $15)$ & \multirow{2}{*}{$\begin{array}{l}0.39 \\
(17)\end{array}$} \\
\hline & SS & $13.88 \pm 0.07$ & 10 & & $13.45 \pm 0.29$ & 4 & \\
\hline \multirow{2}{*}{$\begin{array}{c}\text { Valdemoro } \\
1987\end{array}$} & $\mathrm{BB}$ & $14.07 \pm 0.19$ & $10)$ & \multirow{2}{*}{$\begin{array}{l}1.50 \\
(18)\end{array}$} & $13.22 \pm 0.24$ & $10\}$ & \multirow{2}{*}{$\begin{array}{l}0.07 \\
(18)\end{array}$} \\
\hline & BS & $14.54 \pm 0.25$ & $10\}$ & & $13.20 \pm 0.16$ & 10 & \\
\hline
\end{tabular}

*Significant at the 5 per cent level.

Table 2 Mean cell chiasma frequencies of male and female individuals of $E$. pulvinatus with different karyomorphs for $M 7$ and S8 chromosomes. $N=$ nos of individuals

\begin{tabular}{|c|c|c|c|c|c|c|c|c|}
\hline \multirow[b]{2}{*}{ Population } & \multicolumn{2}{|c|}{ Karyomorph } & \multirow[b]{2}{*}{$\begin{array}{l}\text { Males } \\
X^{\prime}+a / \text { cell }\end{array}$} & \multirow[b]{2}{*}{$N$} & \multirow[b]{2}{*}{$t$-test } & \multirow[b]{2}{*}{$\begin{array}{l}\text { Females } \\
X^{-} \text {ta/cell }\end{array}$} & \multirow[b]{2}{*}{$N$} & \multirow[b]{2}{*}{$t$-test } \\
\hline & M7 & S8 & & & & & & \\
\hline \multirow{4}{*}{$\begin{array}{c}\text { Desviación } \\
1989\end{array}$} & $\mathrm{BB}$ & $\mathrm{BB}$ & $13.13 \pm 0.16$ & 10 & \multirow{2}{*}{$3.0^{*}$} & $13.37 \pm 0.20$ & 8) & \multirow{2}{*}{0.27} \\
\hline & BS & $\mathrm{BB}$ & $13.86 \pm 0.09$ & $5\}$ & & $13.43 \pm 0.06$ & 3) & \\
\hline & BS & BS & $13.91 \pm 0.29$ & 7 & & & & \\
\hline & $\mathrm{BS}$ & BS & $14.12 \pm 0.58$ & & & & & \\
\hline
\end{tabular}

*Significant at the 5 per cent level. 


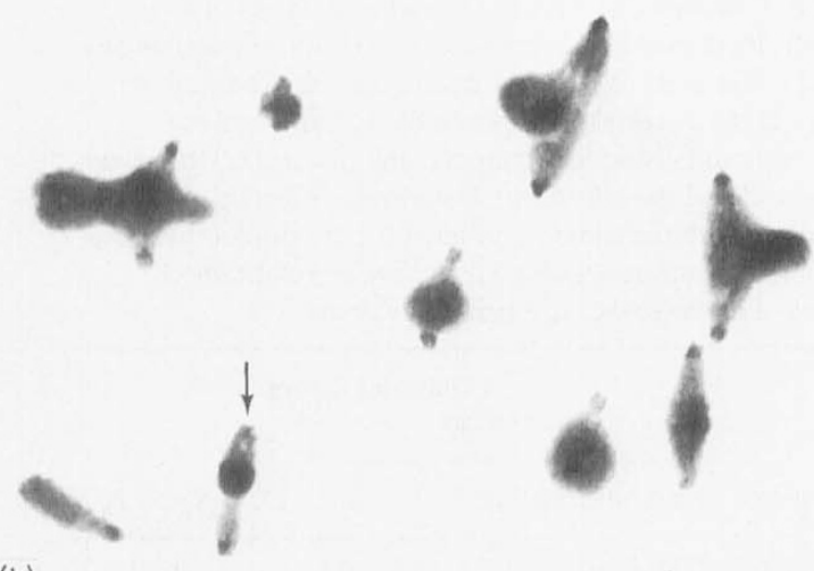

(b)

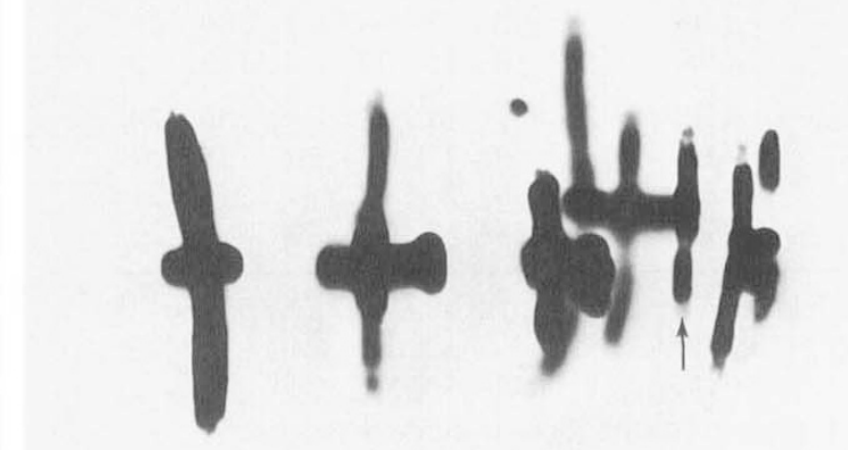

(d) (a)

.

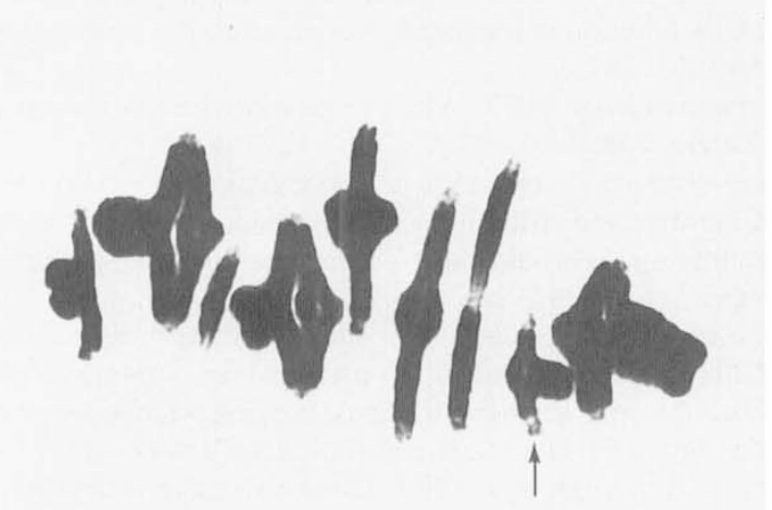

(c)

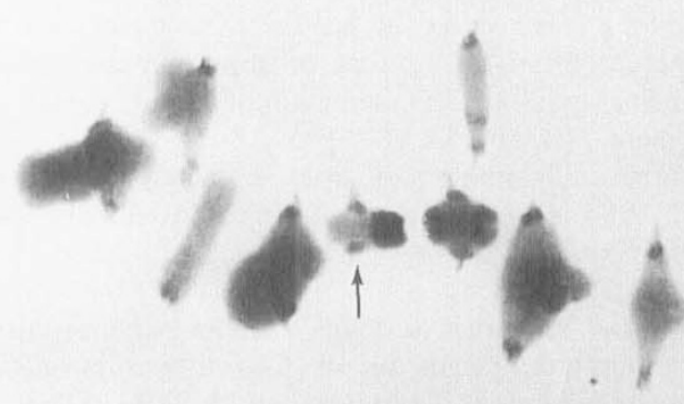

Fig. 2 ( $a$ and $b$ ) C-banded metaphase I cells from spermatocytes in which M7 bivalent (arrows) shows (a) a proximal chiasma and (b) a distal chiasma. ( $c$ and d) Meiotic first metaphase I cells from oocytes in which M7 bivalent (arrows) shows (c) an interstitial chiasma and (d) a distal chiasma.

the segment are preferred for chiasma formation. The intensity of the effect may be dependent on the size of the segment (Navas-Castillo et al., 1987). This effect may be related to the pairing process exhibited by bivalents heterozygous for such segments (J. L. Santos et al., 1993).

A model to quantify genetic recombination within chromosome regions affected by segments has been proposed by de la Torre et al. (1987). The parameters of this model are the pattern of chiasma distribution in the male, the frequency of each karyomorph in the population, and the general assumption that genic complexes in chromosome regions near segments confer a selective advantage. The results of the present work indicate that in E. pulvinatus a sex-dependent pattern of chiasma distribution is displayed by M7 BS bivalents (Table 3 ), such that only genes close to the extra heterochromatin could be preserved as supergenes. However, structural homozygotes show a chiasma distribution similar to that of basic homozygotes, indicating that recombination occurs in regions adjacent to the segment. Following de la Torre's model, a flexible polymorphism with local adaptations could be generated, although the frequency of M7 segment-bearing chromosomes is quite similar in all populations analysed (Santos \& Giráldez, 1982). In the S8 bivalent the dynamics of the polymorphism would be different, at least in males, because genes located between the centromere and the additional C-band would be affected by crossing-over with a low frequency both in heterozygotes and structural homozygotes.

In addition to hypotheses concerning segment effects on recombination and the preservation of supergenes, other alternatives, such as an equilibrium between a non-Mendelian mode of inheritance and a decrease in the fitness of the carriers, can also be proposed. These await experimental validation in grasshoppers. 
Table 3 Chiasma distributions in different types of M7 bivalents from males and females of two natural populations. Four chromosome regions are distinguished: $\operatorname{proximal}(\mathrm{P})$, interstitial (I), distal (D1) (between the C-band and the centromere in BS and SS bivalents) and distal (D2) (between the $\mathrm{C}$-band and the telomere). Data from different individuals with the same karyomorph were pooled because no significant differences between them were obtained. $N=$ nos of individuals, $N_{\mathrm{b}}=$ nos of bivalents

\begin{tabular}{|c|c|c|c|c|c|c|c|}
\hline \multirow[b]{2}{*}{ Population } & \multirow[b]{2}{*}{ Karyomorph } & \multicolumn{4}{|c|}{$\begin{array}{l}\text { Chiasma location } \\
(\%)\end{array}$} & \multirow[b]{2}{*}{$N_{\mathrm{b}}$} & \multirow[b]{2}{*}{$N$} \\
\hline & & $\mathrm{P}$ & I & D1 & D2 & & \\
\hline \multirow{5}{*}{$\begin{array}{l}\text { Desviación } \\
1989\end{array}$} & ㅇ BB & - & 6 & 94 & - & 80 & 8 \\
\hline & \% $\mathrm{BS}$ & 4 & 96 & - & - & 25 & $5^{*}$ \\
\hline & ơ BB & 20 & 12 & 68 & - & 820 & 82 \\
\hline & o $\mathrm{BS}$ & 93 & 5 & - & 2 & 280 & 28 \\
\hline & ơ SS & 18 & 15 & 77 & - & 155 & 3 \\
\hline \multirow{4}{*}{$\begin{array}{l}\text { Valdemoro } \\
1987\end{array}$} & q BB & 1 & 11 & 88 & - & 200 & 20 \\
\hline & \& BS & 3 & 77 & - & 20 & 35 & 7 \\
\hline & $\sigma^{t} \mathrm{BB}$ & 9 & 24 & 67 & - & 348 & 24 \\
\hline & $O^{\prime} \mathrm{BS}$ & 54 & 4 & - & 42 & 400 & 20 \\
\hline
\end{tabular}

*Three females were M7BS-S8BB, one M7BS-S8BS and another M7BS-S8SS.

Table 4 Chiasma distributions in different types of S8 bivalents from males of two natural populations. Three chromosome regions have been distinguished in each bivalent: Proximal (P), interstitial (I) and distal (D). Data from different individuals with the same karyomorph have been pooled because they showed similar patterns of chiasma distribution. $N=$ nos of individuals, $N_{\mathrm{b}}=$ nos of bivalents

\begin{tabular}{clrrrrrr}
\hline & & \multicolumn{5}{c}{$\begin{array}{l}\text { Chiasma } \\
\text { location (\%) }\end{array}$} \\
\cline { 4 - 7 } Population & Karyomorph & $N$ & \multicolumn{1}{c}{ P } & I & D & $N_{\mathrm{b}}$ \\
\hline Valdemoro & BB & 10 & 5 & 27 & 68 & 146 \\
1987 & BS & 10 & 1 & 15 & 84 & 134 \\
Desviación & BB & 40 & 17 & 21 & 62 & 497 \\
1989 & BS & 30 & 6 & 32 & 62 & 354 \\
& SS & 30 & 6 & 17 & 77 & 371 \\
\hline
\end{tabular}

\section{Acknowledgements}

I would like to thank Dr M. I. Cano and Mr E. Espeso for their technical assistance.

\section{References}

CABRERo, J., NAVAS-CASTILlo, J. AND CAMACHO, J. P. M. 1986. Effects of supernumerary segments on the activity of nucleolar organiser regions in the grasshopper Chorthippus binotatus. Chromosoma, 93, 375-380.

CAMACHO, J. P. M., VISERAS, E., NAVAS, J. AND CABRERO, J. 1984. C-heterochromatin content of supernumerary chromosomes of grasshoppers: detection of an euchromatic extra segment. Heredity, 53, 167-175.

HENRIQUES-GIL, N., JONES, G. H., CANO, M. I., ARANA. P. AND SANTOS, J. L. 1986. Female meiosis during oocyte maturation in Eyprepocnemis plorans (Orthoptera, Acrididae). Can. J. Genet. Cytol., 28, 84-87.

HEWITT, G. M. AND JOHN, B. 1968. Parallel polymorphism for supernumerary segments in Chorthippus parallelus. I. British populations. Chromosoma, 25, 319-342.

JOHN, B. 1981. Hetechromatin variation in natural populations. In: Chromosomes Today 7. George Allen and Unwin, New York, pp. 128-137.

MIKLOS, G. L. C. AND NANKIVELL, R. N. 1976. Telomeric satellite DNA function in regulating recombination. Chromosoma, 56, 143-167.

MAYNARD-SMITH, J. 1977. Why the genome does not congeal? Nature, 268, 693-696.

NAVAS-CASTILlO, J., CABRERO, J. AND CAMACHO, J. P. M. 1985. Chiasma redistribution in bivalents carrying supernumerary chromosome segments in grasshoppers. Heredity, 55, 245-248.

NAVAS-CASTILlo, J., CABRERO, J. AND CAMACHO, J. P. M. 1987. Chiasma redistribution in presence of supernumerary chromosome segments in grasshoppers: dependence on the size of the extra segment. Heredity, 58, 409-414.

REES, H. AND DALE, P. J. 1974. Chiasmata and variability in Lolium and Festuca populations. Chromosoma, 47, 335-351.

SANTOS, J. L. AND ESTEBAN, M. R. 1990. On the nature of meiotic associations involving heterochromatic ends in grasshoppers. Genome, 33, 725-728.

SANTOS, J. L. AND GIRALDEZ, R. 1978. The effect of C-heterochromatin in chiasma terminalization in Chorthippus biguttulus L. (Acrididae, Orthoptera). Chromosoma, $\mathbf{7 0}$, 59-66.

SANTOS, J. L. AND GIRALDEZ, R. 1982. C-heterochromatin polymorphism and variation in chiasma localization in Euchorthippus pulvinatus (Acrididae, Orthoptera). Chromosoma, 85, 507-518.

SANTOS, J. L., CERRO DEL A., FERNANDEZ, A. AND DIEZ, M. 1993. The relationship between synapsis and chiasma distribution in grasshopper bivalents heterozygous for supernumary segments. Heredity, 70, 135-141.

SHAW, D. D. 1971. The supernumerary segment system of Stethophyma. II. Heterochromatin polymorphism and chiasma variation. Chromosoma, 34, 19-39.

TORRE, J. DE LA, LOPEZ-FERNANDEZ, C., NICHOLS, R. AND GOSALVEZ, J. 1986. Heterochromatin readjusting chiasma distribution in two species of the genus Arcyptera. The effect among individuals and populations. Heredity, 56, 177-184.

TORRE, J. DE LA, TORROJA, E., GOSALVEZ, J. AND LOPEZ-FERNANDEZ, C. 1987. A model for quantifying genetic recombination in chromosome polymorphisms due to supernumerary heterochromatic segments. Heredity, 58, 345-349. 